\title{
Screening for probiotic of lactic acid bacteria isolated from the digestive tract of a native Aceh duck (Anas platyrhynchos)
}

\author{
YAYUK KURNIA RISNA ${ }^{1,2}$, SRI HARIMURTI', WIHANDOYO ${ }^{2}$, WIDODO ${ }^{2, \%}$ \\ ${ }^{1}$ Faculty of Agriculture, Universitas Al Muslim. Matangglumpangdua, Bireuen 24261, Aceh, Indonesia \\ ${ }^{2}$ Faculty of Animal Science, Universitas Gadjah Mada. J1. Fauna No. 3, Karang Gayam, Sleman 55281, Yogyakarta, Indonesia. Tel.: +62-274-513363, \\ vemail: widodohs@ugm.ac.id
}

Manuscript received: 23 April 2020. Revision accepted: 11 June 2020

\begin{abstract}
Risna YK, Harimurti S, Wihandoyo, Widodo. 2020. Screening for Probiotic of lactic acid bacteria isolated from the digestive tract of a native Aceh duck (Anas platyrhynchos). Biodiversitas 21: 3001-3007. The lactic acid bacteria (LAB) isolated from the digestive tract of a native Aceh duck has emerged as a potential probiotic supplement for duck feed. In this study, we isolated the LAB from the digestive tract of an Aceh duck (Anas platyrhynchos) and identified the species and bacterial characteristics. Additionally, we isolated the LAB used in this study from the crop, proventriculus, ventriculus, duodenum, jejunum, ileum, and cecum of the native Aceh duck. Identification included the examination of morphology and physiology, followed by molecular identification by using 16S rRNA and sequence similarity tests for the bile salt hydrolase $(b s h)$ gene. Bacterial isolation from the digestive tract of this duck resulted in 19 isolates with gram-positive, negative catalase, and non-motile characteristics. Of the 19 isolates, 11 isolates exhibited the ability to grow at $15^{\circ} \mathrm{C}, 37^{\circ} \mathrm{C}$, and $45^{\circ} \mathrm{C}$, with optimum growth at $37^{\circ} \mathrm{C}$. From 11 isolates, only 6 were identified by using $16 \mathrm{~S}$ rRNA primers and 5 were identified by using BSH primers. The identified LAB included Lactobacillus plantarum, Lactobacillus fermentum, and Pediococcus acidilactici. Hence, we conclude that Lactobacillus sp and Pediococcus sp. are potential probiotics that can be isolated and administered for duck feed.
\end{abstract}

Keywords: Aceh duck, lactic acid bacteria, probiotics, poultry

\section{INTRODUCTION}

Since 2006, The European Union has banned the use of all antibiotic growth promoters for livestock production because the residuals from these drugs contaminate commercial products (Fernandez et al. 2014). The ban on antibiotic use occurred due to the emergence of resistant bacteria and the concern that antibiotic residues in meat and eggs might lead to potential health hazards in the consumers. The major health risk associated with antibiotics is the development of resistant microbiota in the gastrointestinal tract (Diarra et al. 2010). In Indonesia, the Indonesian Constitution no. 41 on Livestock and Animal Health had imposed a ban on antibiotics as a feed additive in 2014. In 2017, the Indonesian Ministry of Agriculture issued the Regulation of the Ministry of Agriculture Ministerial no. 14 on Animal Drugs Classification, which explicates the ban on antibiotics for use as a feed additive.

The poultry industry has used antibiotics to prevent bacterial infection on poultry farms. More than $60 \%$ of all the produced antibiotics are used in animal production for both therapeutic and non-therapeutic purposes (Van Boeckel et al. 2015). In Indonesian poultry production, antibiotics have been effectively used to inhibit the actions of poultry-associated pathogens from the various serotypes of Escherichia coli, Campylobacter jejuni, and Salmonella enterica (Sri-Harimurti and Hadisaputro 2015). However, the use of antibiotics in poultry production had been reported to increase antibiotic residues in meat and eggs (Mund et al. 2017, Mehdi et al. 2018). The results of a few studies have revealed that a sample of $8.3 \%(2 / 24)$ of positively tested chickens contained antibiotic residues of oxytetracycline. Meanwhile, $75 \%$ (18/24) of the positive egg samples contained antibiotic residues of penicillin, $12.5 \%(3 / 24)$ of these samples contained positive residues of aminoglycoside, and $12.5 \%(3 / 24)$ of these samples contained positive residues of oxytetracycline (Widiasih et al. 2019).

Because the detrimental effects of antibiotics are well documented, researchers have been prompted to think about alternatives to antibiotics. A study has proposed the use of probiotics as an alternative to antibiotics in poultry feed (Mehdi et al. 2018). The Food and Agriculture Organization (FAO) and World Health Organization (WHO) have defined probiotics as "live microorganisms which, when administered in adequate amounts, confers a health benefit on the host" (FAO/WHO 2001; Aziz and Bonavida 2016). Lactic acid bacteria (LAB) are the commonly utilized probiotics in poultry production. LAB are mostly gram-positive, non-motile, rod- and coccusshaped, non-spore-forming bacteria that can grow at $10^{\circ} \mathrm{C}$ to $45^{\circ} \mathrm{C}$. They can optimally grow at a $\mathrm{pH}$ of $5.5-5.8$ and are anaerobic (the ability to survive in the absence of oxygen) (Khalid 2011). The beneficial effects of probiotics have been attributed to their ability to suppress the growth of pathogens via the secretion of antibacterial substances such as lactic acid, peroxides, and bacteriocins (Mokoena 2017).

Vila et al. (2010) previously reported that some species of LAB produced enough hydrogen peroxide to inhibit the 
growth and action of various microorganisms. Lactobacillus acidophilus produces acidophilin and acidolin, whereas L. plantarum produces bacteriocin (Pato et al. 2020, Aritonang et al. 2019). Nisin and diplococcin are among some of the antibiotics produced by Streptococci. Aritonang et al. (2019) reported that the application of bacteriocin produced by L.plantarum SRCM1 00434 was able to preserve beef sausage. Bacillus cereus produces a bacteriocin-like substance that inhibits closely related Bacillus spp. and species such as Staphylococcus aureus and Micrococcus luteus, which exhibited high activity in the $\mathrm{pH}$ range of 3.0-9.0 (Butkhot et al. 2019).

The addition of LAB replaces the enteric pathogens by means of competitive exclusion in the poultry's intestinal tract and subsequently reduces bacterial contamination and increases productivity during poultry production. SriHarimurti and Ariyadi (2010) previously reported that indigenous $\mathrm{LAB}$ isolated from the digestive tract of healthy Indonesian native chickens (Ayam kampung), which consisted of L.murinus Ar3, Streptococcus thermophilus $\mathrm{Kd} 2$, and Pediococcus acidilactici Kp6, proved to be efficient as a feed supplement in improving the live performances of broiler chickens. The isolation of LAB from the digestive tract of poultry aims to obtain the endogenous probiotic bacteria that possess the ability to inhabit and grow inside the digestive tract of the poultry (Sri-Harimurti and Hadisaputro 2015). Therefore, the ideal probiotics for poultry should have a poultry origin because the probiotic bacteria can already effectively colonize the digestive tract of the host (Hibbing et al. 2010).

There has been increased development of probiotic supplementation by using LAB, but LAB isolates originated from the digestive tract of Indonesian local ducks have not yet been reported. In this study, we report the isolation and identification of strains of LAB from the digestive tract of the native Aceh duck to be used as potential probiotics.

\section{MATERIALS AND METHODS}

\section{Sample collection}

We obtained the samples used in the experiments from the digestive tract of a one-year-old native Aceh duck. Three ducks were obtained from a local farmer in Aceh, and was euthanized and humanely killed by severing the jugular vein. The intestines were immediately harvested, and the samples were obtained from the duck's crop, proventriculus, ventriculus, duodenum, jejunum, ileum, and cecum. The samples were collected aseptically in sterilized tubes, which were kept in ice $\left( \pm 4^{\circ} \mathrm{C}\right)$ during transportation to the laboratory until further analysis.

\section{Bacterial isolation and morphology identification}

Bacterial isolation was conducted by following the method developed by Kimprasit et al. (2013) with modifications. Briefly, the freshly prepared samples were washed with phosphate-buffered saline solution and scraped. Next, $10 \mathrm{~mL}$ solution of the samples were inoculated onto sterilized de Man, Rogosa, and Sharpe (MRS) broth (Merck, Germany) media containing 1\% $\mathrm{CaCO}_{3}$ and $0.05 \%$ of bile salts (Oxoid, Singapore). Thereafter, the mixture was incubated at $37^{\circ} \mathrm{C}$ for $24-48 \mathrm{~h}$ in micro-aerobic conditions. This led to the formation of a clear zone, which indicated the production of lactic acid by the putative LAB. White colonies surrounding the clear zone were subjected to morphology and physiology identification, including gram staining; shape, spore formation; motility; catalase test; growth at $15^{\circ} \mathrm{C}, 37^{\circ} \mathrm{C}$, and $45^{\circ} \mathrm{C}$; and production of $\mathrm{CO}_{2}$.

\section{Bacterial growth at different temperatures}

The ability of isolates to grow at different media and temperatures was tested at $15^{\circ} \mathrm{C}, 37^{\circ} \mathrm{C}$, and $45^{\circ} \mathrm{C}$ for $24 \mathrm{~h}$. The healthy culture of the selected five isolates $(\mathrm{C} 1, \mathrm{~V} 2$, D3, J2, I1, and S4) in $1 \mathrm{~mL}$ was inoculated into 9-mL MRS broth and incubated overnight at $37^{\circ} \mathrm{C}$. The overnight cultures were harvested, and two $2 \mathrm{~mL}\left(10^{8} \mathrm{CFU} / \mathrm{mL}\right)$ of the cultures of each isolate were inoculated into $50-\mathrm{mL}$ MRS broth and incubated at $15^{\circ} \mathrm{C}, 37^{\circ} \mathrm{C}$, and $45^{\circ} \mathrm{C}$ for $24 \mathrm{~h}$ in the micro-aerobic condition. Bacterial growth was measured before and after incubation with the help of optical density (OD) spectrophotometer set at the absorbance $\lambda=640 \mathrm{~nm}$. Biomass increase was presented in percentage $(\%)$ and was calculated as: [ (final OD - initial OD) / (initial OD)] $\times 100 \%$.

\section{Genomic DNA extraction and amplification}

Genomic DNA of the selected isolates was extracted by using a Favorgen ${ }^{\mathrm{TM}}$ kit (Favorgen, Taiwan) and complying with the manufacturer's instructions. Genomic DNA amplification was conducted by using polymerase chain reaction (PCR). The GoTag Green ready mix consisted of $25 \mu \mathrm{L}$ of GoTag ready mix solution, $2 \mu \mathrm{L}$ of forward primer, $2 \mu \mathrm{L}$ of $1429 \mathrm{R}$ reverse primer, and $2 \mu \mathrm{L}$ of the DNA sample. The primer pairs used in this study were $27 \mathrm{~F}$ with 1429R (Gong et al. 2007), bshlpF with bshlpR, and $b s h l f \mathrm{~F}$ with bshlfR (Kumar et al. 2012) (Table 1). The amplification was performed by using a PCR thermal cycler with the following cycles: (i) initial denaturation at $95^{\circ} \mathrm{C}$ for $5 \mathrm{~min}$, (ii) denaturation at $95^{\circ} \mathrm{C}$ for $30 \mathrm{~s}$, (iii) annealing at $57^{\circ} \mathrm{C}$ for $30 \mathrm{~s}$, (iv) elongation at $72^{\circ} \mathrm{C}$ for $30 \mathrm{~s}$, (v) final elongation at $72^{\circ} \mathrm{C}$ for $10 \mathrm{~min}$, and (vi) cooling at $4^{\circ} \mathrm{C}$ for $10 \mathrm{~min}$. All of the PCR amplification procedures were repeated for 35 cycles (Xie et al. 2015). The amplified product was further confirmed via electrophoresis by using $2.0 \%$ agarose gel. It was photographed under an ultraviolet illuminator.

\section{DNA sequencing and phylogenetic analysis}

The amplified DNA was sequenced by using 1st BASE DNA Sequencing (Genetika Science Ltd., Indonesia). Thereafter, the obtained sequence was compared with the 16S rRNA database available in GeneBank. The obtained sequences were confirmed by using the Basic Local Alignment Search Tool (BLAST) available at http://blast.ncbi.nlm.nih.gov. The DNA sequence that had close similarity up to $100 \%$ was determined and aligned with the MEGA X program to construct the phylogenetic tree. 
Table 1. Primer pairs used for PCR amplification

\begin{tabular}{lll}
\hline Primer & Primer & Sequences (Gong et al. 2007; Kumar et al. 2012) \\
\hline 16S rRNA & $27 \mathrm{~F}$ & $5^{\prime}$-AGAGTTTGATCCTGGCTCAG-3' \\
& $1429 \mathrm{R}$ & $5^{\prime}$-TAGGGTTACCTTGTTACGACTT-3' \\
Lactobacillus plantarum & bshlp $\mathrm{F}$ & $5^{\prime}$-GCTGAATCACTCCCGGATTT-3' \\
& bshlp $\mathrm{R}$ & $5^{\prime}$-CGAGCTTCGCCTGCTTAATA-3' \\
Lactobacillus fermentum and & bshlf $\mathrm{F}$ & $5^{\prime}$-GCCGCACCTGGATCAAAT-3' \\
Pediococcus acidilactici & bshlf $\mathrm{R}$ & $5^{\prime}$-GGGTGAAGTCTAGGTAGTCCTG-3' \\
\hline
\end{tabular}

\section{Data analysis}

Data obtained from the morphology, physiology, and molecular identification were analyzed by using descriptive statistics for describing the basic features of the data (Thompson 2009).

\section{RESULTS AND DISCUSSION}

\section{Isolation and identification of LAB from the digestive tract of a native Aceh duck}

The results showed that all isolates obtained from the digestive tract of a native Aceh duck could grow on MRS broth media supplemented with $1 \% \mathrm{CaCO}_{3}$ after $24 \mathrm{~h}$ of incubation at $37^{\circ} \mathrm{C}$. The addition of $\mathrm{CaCO}_{3}(1 \%)$ was used to improve the selection of $\mathrm{LAB}$, as indicated by the formation of clear zone. In total, 56 isolates were obtained and selected by using this method. The morphological observations showed that the isolates were either rod- or coccus-shaped; were white, brown, or pink; had convex and shiny surfaces, and were flat or fiber-edged. The obtained isolates that showed similar characteristics as LAB were selected for further identification. From a total of 56 isolates, only 19 isolates showed characteristics of LAB, such as gram-positive, catalase-negative, and nonmotile (Table 2). These 19 isolates were selected for further molecular identification.

In total, 19 selected isolates from the digestive tract of a native Aceh duck were gram-positive, which was indicated by the crystal violet color retained after staining (Black and Black 2018). This phenomenon occurs because grampositive bacteria have a thick layer of peptidoglycan $(50 \%-$ $90 \%$ of the cell weight) in the cell walls, whereas gramnegative bacteria have thinner layers $(10 \%$ of the cell weight) (Dorr et al. 2019). LAB are categorized as grampositive bacteria (Mattu dan Chauchan 2013; Lawalata et al. 2011, Franz et al. 2010). The bacterial cell staining also showed that 14 selected isolates were rod-shaped, whereas the other 5 isolates were coccus-shaped (Table 2). These results were similar to those reported by Xie et al. (2015) who also studied the digestive tract of ducks and reported that the isolated LAB was gram-positive and either rod- or coccus-shaped (Xie et al. 2015). Conversely, Hidayat et al. (2018) reported that the bacteria isolated from the digestive tract of broiler chickens were solely gram-positive cocci. The catalase examined the bacterial capability to produce the catalase enzyme. The catalase enzyme catalyzes the decomposition of hydrogen peroxide $\left(\mathrm{H}_{2} \mathrm{O}_{2}\right)$ into water $\left(\mathrm{H}_{2} \mathrm{O}\right)$ and oxygen $\left(\mathrm{O}_{2}\right)$. If the microbe is catalase-positive, then the sample shows the production of gas bubbles when $3 \% \mathrm{H}_{2} \mathrm{O}_{2}$ was added, thereby indicating the production of $\mathrm{O}_{2}$. For $\mathrm{LAB}$ that are categorized as catalase-negative (Khalid 2011), no gas bubble production was observed. Lactobacillus is a genus of LAB that is categorized as catalase-negative (Kabir et al. 2016).

The motility test was conducted to observe the bacterial motility and the dispersion of bacterial growth along the stabbed line of the media. Our data showed that all of the 19 isolates were non-motile (Table 2). This finding was in agreement with the previous findings that showed that the LAB was non-motile (Khalid 2011).

The growth of selected isolates in this study was observed at three different temperatures, namely, $15^{\circ} \mathrm{C}$, $37^{\circ} \mathrm{C}$, and $45^{\circ} \mathrm{C}$, for $24 \mathrm{~h}$. The OD test with absorbance at $640 \mathrm{~nm}(\lambda=640 \mathrm{~nm})$ showed that all of the selected isolates were able to grow at all of the different temperatures (Figure 1), with an optimal growth temperature of $37^{\circ} \mathrm{C}$ as this temperature demonstrated the highest biomass increase following growth for $24 \mathrm{~h}$. This observation suggested that LAB were mesophilic bacteria. However, some species had the ability to grow at $45^{\circ} \mathrm{C}$ (Mulaw et al. 2019).

As all of the 19 isolates had the potential LAB, all isolates underwent further molecular identification either by using a $16 \mathrm{~S}$ rRNA approach or the bile salt hydrolase (bsh) gene to determine similarity with other LAB members. From the 19 isolates, only 11 isolates were identified; 6 isolates (C1, V2, D3, J2, I1, and S4) were identified by using $16 \mathrm{~S}$ rRNA amplification, and 5 isolates (C1, V2, D3, I1, and S4) were identified by using $b s h$ amplification. The rest of 8 isolates were not able to be identified either by using $16 \mathrm{~S}$ rRNA or $b s h$ gene. By using $16 \mathrm{~S}$ rRNA as primers, 6 isolates $(\mathrm{C} 1, \mathrm{~V} 2, \mathrm{D} 3, \mathrm{~J} 2, \mathrm{I} 1$, and S4) had amplified bands at 1500 bp in length (Figure 2), which agreed with the target of amplification. Then, the amplified bands were sequenced.

The amplified bands obtained in Figure 2 were sequenced, and the resulting sequences were analyzed by using the BLAST program for determining the similarity of sequences across the full bacterial 16S rRNA gene bank recorded by GenBank. The BLAST analysis showed that the $\mathrm{C} 1$ isolate was genetically similar to L. plantarum; the $\mathrm{V} 2$ and $\mathrm{J} 2$ isolates were similar to P.acidilactici; and the D3, I1, and S4 isolates were similar to L. fermentum (Table 3). According to Claverie and Notredame (2007), two or more sequences are categorized as a homolog when the nucleotide show more than $70 \%$ of the similarity. 
Table 2. Morphology and physiology of selected isolates

\begin{tabular}{|c|c|c|c|c|c|c|}
\hline Isolation spot & Code & Gram stain & Shape & Catalase & Motility & $\mathrm{CO}_{2}$ detection \\
\hline Crop & $\mathrm{C} 1$ & Positive & Rod & - & - & - \\
\hline Crop & $\mathrm{C} 2$ & Positive & Rod & - & - & - \\
\hline Crop & $\mathrm{C} 3$ & Positive & Rod & - & - & - \\
\hline Proventriculus & $\mathrm{P} 1$ & Positive & Rod & - & - & + \\
\hline Ventriculus & V1 & Positive & Coccus & - & - & + \\
\hline Ventriculus & $\mathrm{V} 2$ & Positive & Coccus & - & - & - \\
\hline Duodenum & D1 & Positive & Rod & - & - & + \\
\hline Duodenum & D2 & Positive & Rod & - & - & - \\
\hline Duodenum & D3 & Positive & Rod & - & - & + \\
\hline Jejunum & $\mathrm{J} 1$ & Positive & Coccus & - & - & + \\
\hline Jejunum & $\mathrm{J} 2$ & Positive & Coccus & - & - & + \\
\hline Jejunum & $\mathrm{J} 3$ & Positive & Coccus & - & - & + \\
\hline Ileum & I1 & Positive & Rod & - & - & - \\
\hline Ileum & $\mathrm{I} 2$ & Positive & Rod & - & - & - \\
\hline Ileum & $\mathrm{I} 3$ & Positive & Rod & - & - & - \\
\hline Cecum & S1 & Positive & Rod & - & - & + \\
\hline Cecum & S2 & Positive & Rod & - & - & - \\
\hline Cecum & S3 & Positive & Rod & - & - & - \\
\hline Cecum & S4 & Positive & Rod & - & - & - \\
\hline
\end{tabular}

Note: Catalase test $=$ did not show any gas bubbles $(-)$, Motility test $=$ isolate growth was not dispersed/non-motile $(-), \mathrm{CO}_{2}$ detection test $=$ homofermentative $(-)$; heterofermentative $(+)$

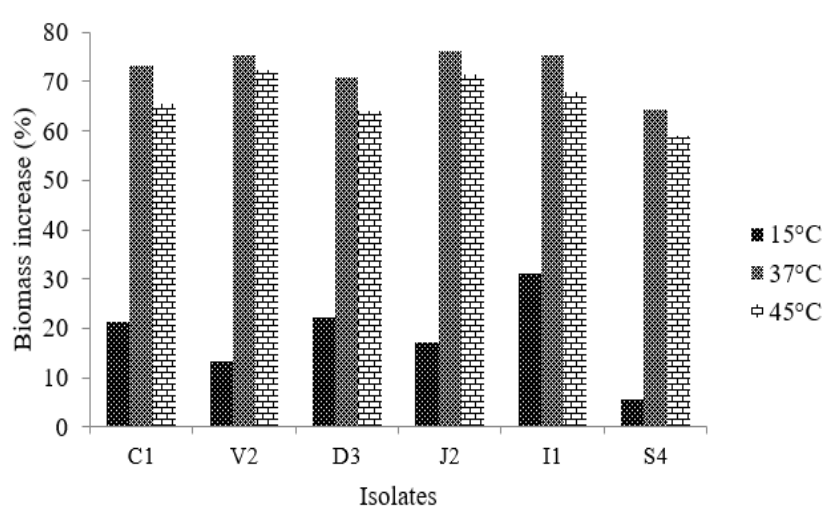

Figure 1. Biomass increase (\%) of the isolates before and after incubation at different temperatures. (A) $15^{\circ} \mathrm{C}$, (B) $37^{\circ} \mathrm{C}$, and (C) $45^{\circ} \mathrm{C}$ for $24 \mathrm{~h}$.

Figure 3 depicts the comparison of the genetic relationship of the isolates $\mathrm{C} 1, \mathrm{~V} 2, \mathrm{D} 3, \mathrm{~J} 2, \mathrm{I} 1$, and $\mathrm{S} 4$ with several partial sequences and a complete genome for some of the strains of Lactobacillus spp. and Pediococcus spp. Herein, the sequence of Clostridium sporosphaeroides $16 \mathrm{~S}$ ribosomal RNA was used as an outgroup.

\section{Bile salt hydrolase (bsh) gene identification}

Six selected isolates (C1, V2, D3, J2, I1, and S4) were also amplified based on the bile salt hydrolase $(b s h)$ gene

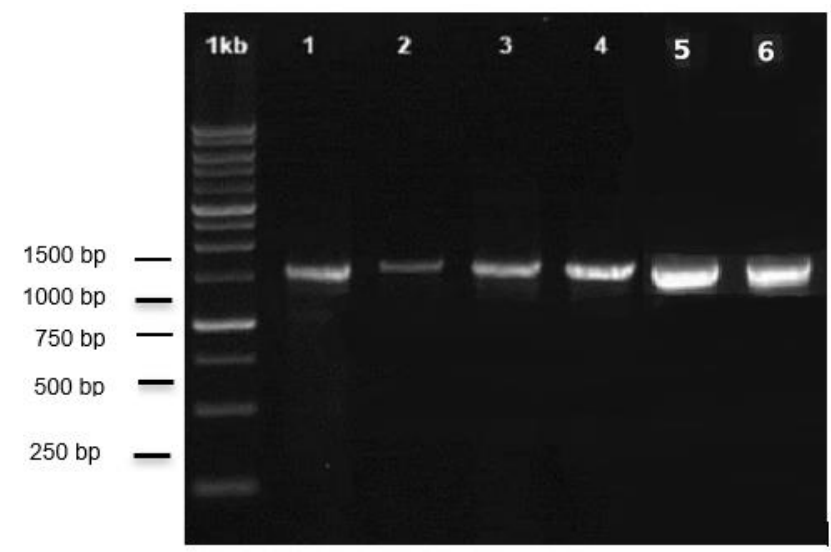

Figure 2. Genomic DNA amplification of six isolates by using the specific $16 \mathrm{~S}$ rRNA primers. $1 \mathrm{~kb}=\mathrm{DNA}$ marker, $1=\mathrm{C} 1$ isolate, $2=\mathrm{I} 1$ isolate, $3=\mathrm{S} 4$ isolate, $4=\mathrm{V} 2$ isolate, $5=\mathrm{D} 3$ isolate, and $6=\mathrm{J} 2$ isolate

by using the specific primers for the $b s h$ gene (Table 1 ), which resulted in five isolates $(\mathrm{C} 1, \mathrm{~V} 2, \mathrm{D} 3, \mathrm{I} 1$, and S4). Furthermore, their DNA samples were amplified (Figure 4). The isolate $\mathrm{J} 2$, which was identified as a strain of $P$. acidilactici by using $16 \mathrm{~S}$ rRNA primer, was unable to be identified by using the $b s h$ primers. Agarose gel electrophoresis showed the amplified bands of $400 \mathrm{bp}$ for C1 and 220 bp for V2, D3, I1, and S4 (Figure 4). 


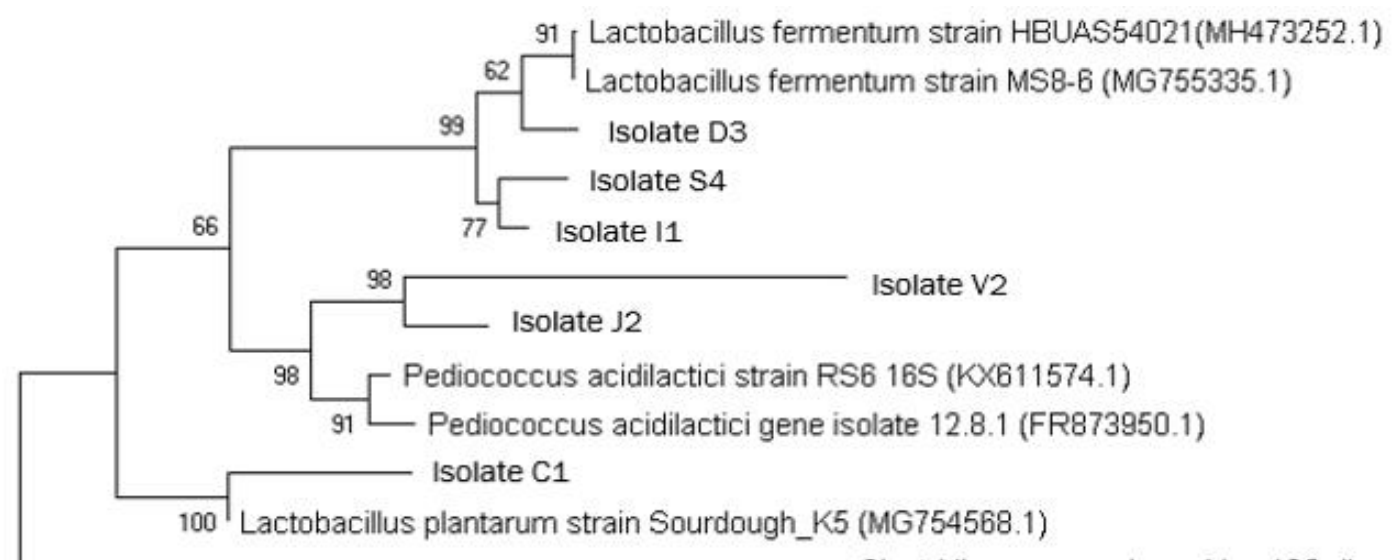

Clostridium sporosphaeroides 165 ribosomal RNA (M59116.1)

0.050

Figure 3. Phylogenetic tree showing the genetic relationship of the isolates D3, S4, I1, V2, J2, and C1 with other species from the genus Lactobacillus and Pediococcus based on their 16S rRNA sequences. The phylogenetic tree was produced by using the neighbor-joining method. The scale bar refers to a phylogenetic distance of 0.05 nucleotide substitutions per site. The numbers on the branches indicate a bootstrap percentage after 1,000 replications. The access code was obtained from The National Center for Biotechnology Information (NCBI) database

Table 3. Comparison of the $16 \mathrm{~S}$ rRNA sequence against the GenBank database.

\begin{tabular}{lll}
\hline Isolate & 16S rRNA & $\begin{array}{l}\text { NCBI- } \\
\text { BLAST } \\
\text { access no. }\end{array}$ \\
\hline C1 & $\begin{array}{l}\text { Lactobacillus plantarum } \text { CE7.11 } \\
\text { 96.14\% }\end{array}$ & MH899287.1 \\
V2 & $\begin{array}{l}\text { Pediococcus acidilactici } \text { RS1 } \\
\text { 90.52\% }\end{array}$ & KX611572.1 \\
D3 & $\begin{array}{l}\text { Lactobacillus fermentum HBUAS53177 } \\
\text { 95.95\% }\end{array}$ & MH393037.1 \\
J2 & $\begin{array}{l}\text { Pediococcus acidilactici isolate 12.8.1 } \\
\text { 94.53\% }\end{array}$ & FR873950.1 \\
I1 & $\begin{array}{l}\text { Lactobacillus fermentum } \text { MS8-6 } \\
\text { 96.52\% } \\
\text { Sactobacillus fermentum HBUAS54021 }\end{array}$ & MH4755335.1 \\
S4 & 96.71\% & \\
\hline
\end{tabular}

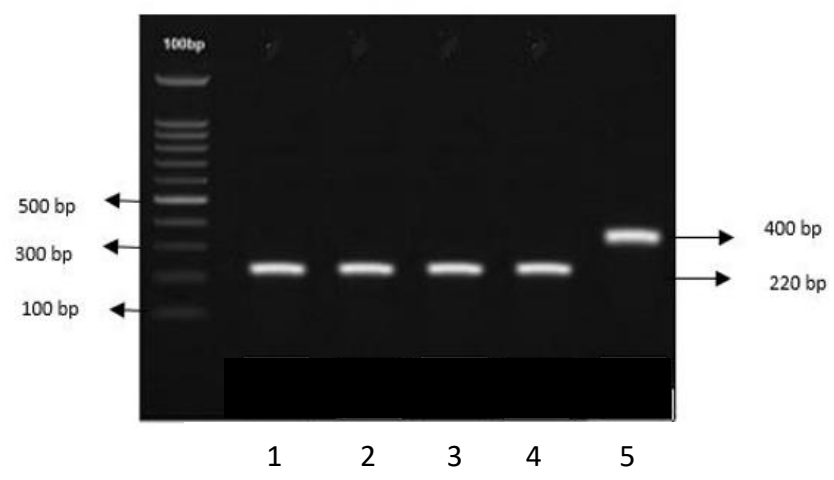

Figure 4. DNA amplification of the five isolates via the $b s h$ genespecific primer $b \operatorname{sh} \mathrm{lf}(1=\mathrm{V} 2,2=\mathrm{D} 3,3=\mathrm{I} 1$, and $4=\mathrm{S} 4)$ and the primer $b \operatorname{shlp}(5=\mathrm{C} 1)$
Table 4. Comparison of the $b s h$ gene sequences against the database in GenBank

\begin{tabular}{lll}
\hline Isolate & bsh gene & $\begin{array}{l}\text { NCBI- } \\
\text { BLAST } \\
\text { access no. }\end{array}$ \\
\hline C1 & $\begin{array}{l}\text { Lactobacillus plantarum bsh2O396 } \\
99.48 \%\end{array}$ & KX266274.1 \\
V2 & $\begin{array}{l}\text { Lactobacillus fermentum } 845 \text { bsh gene } \\
99.46 \%\end{array}$ & KM875458.1 \\
D3 & $\begin{array}{l}\text { Lactobacillus fermentum } 845 \text { bsh gene } \\
99.46 \%\end{array}$ & KM875458.1 \\
I1 & $\begin{array}{l}\text { Lactobacillus fermentum } 845 \text { bsh gene } \\
100.00 \%\end{array}$ & KM875458.1 \\
S4 & $\begin{array}{l}\text { Lactobacillus fermentum } 845 \text { bsh gene } \\
100.00 \%\end{array}$ & KM875458.1 \\
\hline
\end{tabular}

The amplified bands were sequenced, and the resulting sequences were used for searching similarity with other bacterial $b s h$ gene sequences that are available in GenBank by using the BLAST program. The results of the BLAST analysis showed a high DNA similarity (99\%-100\%) with several $b s h$ genes for each species of $L$. plantarum and $L$. fermentum, as presented in Table 4.

The BLAST analysis of $b s h$ gene sequence showed that the $\mathrm{C} 1$ isolate was genetically similar to L. plantarum, and the V2, D3, I1 and S4 isolates were similar to L.fermentum (Table 4). The homolog sequences and accession numbers for L. plantarum and L. fermentum from BLAST were used to construct a phylogenetic tree. Figure 5 shows the phylogenetic tree for C1, V2, D3, I1, and S4. 


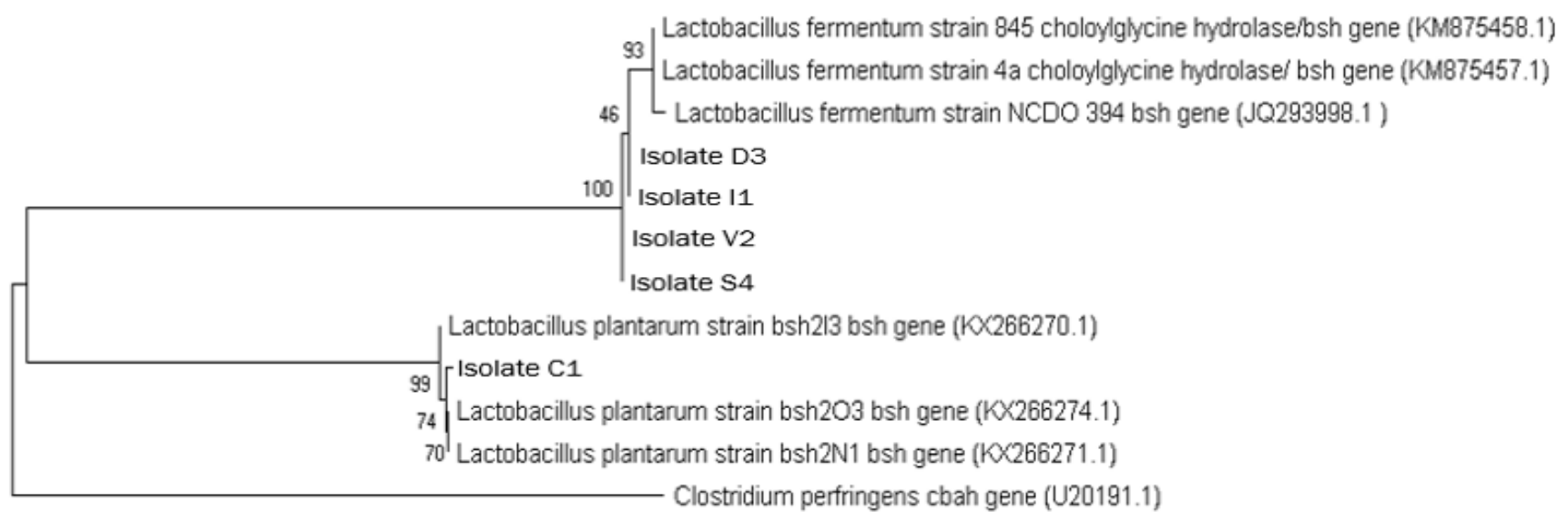

0.20

Figure 5. Phylogenetic tree showing a bsh gene relationship for the isolates D3, I1, V2, S4, C1 with other species of L.plantarum and $L$. fermentum. The phylogenetic tree is produced by using the neighbor-joining method. The scale bar refers to a phylogenetic distance of 0.20 nucleotide substitutions per site. The numbers on the branches indicate a bootstrap percentage after 1000 replications. The access code was obtained from the NCBI database

A comparable result of identification, except for V2, was obtained by either using $16 \mathrm{~S}$ rRNA or $b s h$ gene amplification, further suggesting that DNA sequence similarity tests are effective methods for bacterial identification. BSH is an important enzyme that is produced as a response to the bile salt. The $b s h$ gene is responsible for the production of $\mathrm{BSH}$ enzyme in LAB. The ability to produce $\mathrm{BSH}$ and to tolerate high concentration of bile salt is often classified as one of important traits of probiotics. An interesting finding was observed for the V2 isolate. Based on 16S rRNA amplification sequence, this isolate was identified as a strain of $P$. acidilactici (Table 3). Conversely, based on the $b s h$ gene similarity, it was identified as a strain of $L$. fermentum (Table 4). As isolate V2 was mixed within the species of $P$. acidilactici and L. fermentum, further identification using species-specific primers is required to confirm whether the isolate V2 was a strain of $P$. acidilactici or L. fermentum. Chagnaud et al. (2001) previously reported both conserved regions and variable zones of $16 \mathrm{~S}$ rRNA gene for the identification of LAB at species level, and this finding facilitated the genetic differentiation between $P$. acidilactici or L. fermentum.

In conclusion, based on 16S rRNA sequences, we were able to isolate and identify one isolate similar to $L$. plantarum, two isolates similar to $P$. acidilactici, and three isolates similar to $L$. fermentum obtained from the gastrointestinal tract of Aceh duck. Identification using the $b s h$ gene from the similar isolates showed one isolate similar to the L. plantarum strain bsh20396 and three isolates similar to the L. fermentum strain 845 . The identified LAB strains exhibited optimum growth at $37^{\circ} \mathrm{C}$. In the future, commercially available probiotics of $L$. plantarum, $P$. acidilactici, and L. fermentum originated from ducks could be used to treat poultry against bacterial infection.

\section{ACKNOWLEDGEMENTS}

The authors thank the Indonesian Ministry for Research, Technology, and Higher Education (Kemenristekdikti) for research funding through Beasiswa Unggulan Dosen Dalam Negeri. The authors would also like to thank Ari Surya Sukarno for any technical assistance.

\section{REFERENCES}

Aritonang SN, Roza E, Sandra A. 2019. Application of bacteriocin from Lactobacillus plantarum SRCM1 00434 isolated from okara as a natural preservative in beef sausage. Biodiversitas 21 (5): 2240-2243. DOI: $10.13057 /$ biodiv/d210553.

Azis N, Bonavida B. 2016. Activation of natural killer cells by probiotics. For Immunopathol Dis Therap 7 (1-2): 41-55. DOI: 10.1615/ForumImmunDisTher.2016017095.

Black JG, Black LJ. 2018. Microbiology: Principle and Exploration 10th ed. John Wiley \& Son, New York.

Butkhot N, Soodsawaeng P, Vuthiphandchai V, Nimrat S. 2019. Characterisation and biosafety evaluation of a novel bacteriocin produced by Bacillus velezensis BUU004. Intl Food Res J 26 (5): 1617-1625.

Chagnaud P, Machinis K, Coutte LA, Marecat A, Mercenier A. 2001. Rapid PCR-based procedure to identify lactic acid bacteria: Application to six common Lactobacillus species. J Microbiol Methods 44 (2): 139-148. DOI: 10.1016/s0167-7012 (00)00244-X.

Claverie J-M, Notredame C. 2007. Bioinformatics for Dummies. The $2^{\text {nd }}$ Edition. Wiley Publishing Inc. Indiana, USA.

Diarra MS, Rempel H, Champagne J, Masson L, Pritchard J, Topp E. 2010. Distribution of antimicrobial resistance and virulence genes in Enterococcus spp. and characterization of isolates from broiler chickens. Appl Environment Microbiol 76 (24): 8033-8043. DOI: 10.1128/AEM.01545-10.

Dorr T, Moynihan PJ, Mayer C. 2019. Bacterial cell wall structure and dynamics. Front Microbiol 10: $2501 . \quad$ DOI: 10.3389/fmicb.2019.02051.

Fernandez BCS, Martins MFRB, Mendes AA, Milbradt EL, Sanfelice C, Martins BB, Aguiar EF, Bresne C. 2014. Intestinal integrity and 
performance of broiler chicken fed a probiotic, a prebiotic or organic acid. Braz J Poult Sci 16 (4): 417-424. DOI: 10.1590/1516635X1604417-424.

Franz C, Cho GS, Holzapfel WH, Galvez A. 2010. Safety of Lactic Acid Bacteria. In: Mozzi F, Raya RR, Vignolo GM (eds.). Biotechnology of Lactic Acid Bacteria-Novel Applications. Blackwell Publishing, Iowa.

Gong J, Si W, Foster RJ, Huang R, Yu H, Yin Y, Yang C, Han Y. 2007 $16 \mathrm{~S}$ rRNA gene-based analysis of mucosa-associated bacterial community and phylogeny in the chicken gastrointestinal tracts: from crops to ceca. FEMS Microbiol Ecol 59 (1): 147-157. DOI: 10.1111/j.1574-6941.2006.00193.x.

Hibbing ME, Fuqua C, Parsek MR, Peterson SB. 2010. Bacterial competition: surviving and thriving in the microbial jungle. Nat Rev Microbiol 8 (1): 15-25. DOI: 10.1038/nrmicro2259.

Hidayat MN, Malaka R, Agustina L, Pakiding W. 2018. Characteristics isolate lactic acid bacteria of origin digestive tract of broiler as probiotic candidates for poultry. Intl J Sci Eng Res 9 (2): 1787-1794.

Kabir SML, Rahman SMM, Neogi SB, Rahman MM, Khan MSR. 2016. Isolation, identification, molecular characterization and screening of probiotic activities of Lactobacillus species from poultry sources at live bird markets in Mymensingh, Bangladesh. Asian Australas J Biosci Biotechnol 1 (1): 54-65.

Khalid K. 2011. An overview of lactic acid bacteria. Intl J BioSci 1 (3): 1 13.

Kimprasit T, Sukontasing S, Amavisit P. 2013. In vitro selection of potential lactic acid bacteria isolated from ducks and geese in Thailand. Kasetsart J Nat Sci 47: 261-270.

Kumar R, Rajkumar H, Kumar M, Varikuti SR, Athimamula R, Shujauddin M, Ramagoni R, Kondapalli N. 2012. Molecular cloning, characterization and heterologous expression of bile salt hydrolase (Bsh) from Lactobacillus fermentum NCDO394. Mol Biol Rep 40 (8) 5057-5066. DOI: 10.1007/s11033-013-2607-2.

Lawalata HJ, Sembiring L, Rahayu ES. 2011. Molecular identification of lactic acid bacteria producing antimicrobial agents from Bekasang, an Indonesian fermented fish product. Indon J Biotech 16 (2): 91-99. DOI: $10.22146 /$ ijbiotech.16368.

Mattu B, Chauchan A. 2013. Lactic acid bacteria and its use in probiotics. J Bioremed Biodeg 4: e140. DOI: 10.4172/2155-6199.1000e140.

Mehdi Y, Letourneau-Montminy M-P, Gaucher M-L, Chorfi Y, Suresh G, Rouissi T, Brar SK, Cote C, Ramirez AA, Godbout S. 2018. Use of antibiotics in broiler production: Global impacts and alternatives. Anim Nut 4 (2): 170-178. DOI: 10.1016/j.aninu.2018.03.002.
Mulaw G, Tessema TS, Muleta D, Tesfaye A. 2019. In vitro evaluation of probiotic properties of lactic acid bacteria isolated from some traditionally fermented Ethiopian food products. Intl J Microbiol DOI: $10.1155 / 2019 / 7179514$

Mund MD, Khan UH, Tahir U, Mustafa B-E, Fayyaz A. 2017. Antimicrobial drug residues in poultry products and implications on public health: A review. Intl J Food Proper 20 (7): 1433-1446. DOI: 10.1080/10942912.2016.1212874.

Mokoena MP. 2017. Lactic acid bacteria and their bacteriocins: classification, biosynthesis and applications against uropathogens: a mini-review. Molecules 22 (8): 1255 . DOI: $10.3390 /$ molecules 22081255 .

Minister of Agriculture of the Republic of Indonesia. 2017. Animal Medication Classification. Regulation of the Minister of Agriculture Number 14/PK.350/5/2017. Jakarta, Indonesia.

Pato U, Yusuf Y, Fitriani S, Jonnadi NN, Wahyuni MS, Feruni JA, Jaswir I. 2020. Inhibitory activity of crude bacteriocin produced by lactic acid bacteria isolated from dadih against Listeria monocytogenes. Biodiversitas 21 (4): 1295-1302. DOI: 10.13057/biodiv/d210404.

Sri-Harimurti, Ariyadi B. 2010. Effect of indigenous lactic acid bacteria probiotics on broiler performance. The $5^{\text {th }}$ International Seminar on Tropical Animal Production "Community Empowerment and Tropical Animal Industry". Yogyakarta, Indonesia.

Sri-Harimurti, Hadisaputro W. 2015. Probiotics in poultry. Springer International Publishing, Switzerland.

Thompson CB. 2009. Descriptive data analysis. Air Med J 28 (2): 56-59. DOI: 10.1016/j.amj.2008.12.001.

Van Boeckel TP, Brower C, Gilbert M, Grenfella BT, Levina SA, Robinson TP, Teillanta U, Laxminarayan R. 2015. Global trends in antimicrobial use in food animals. Proc Natl Acad Sci USA 112 (18): 5649-5654. DOI: 10. 1073/pnas.1503141112.

Vila B, Esteve-Garcia A, Brufau J. 2010. Probiotic micro-organisms: 100 years of innovation and efficacy; modes of action. World Poult Sci J 65 (3): 369-380. DOI: 10.1017/S0043933910000474.

Widiasih DA, Drastini Y, Yudhabuntara D, Maya FLRD, Sivalingham PL, Susetya H, Nugroho WS, Putri MTK, Primatika RA, Sumiarto B. 2019. Detection of antibiotic residues in chicken meat and eggs from traditional markets at Yogyakarta City using bioassay method. Acta Vet Indon. DOI: 10.29244/avi.0.0.1-6.

Xie ZL, Bai DP, Xie LN, Zhang WN, Huang XH, Huang YF. 2015. Intestinal lactic acid bacteria from Muscovy duck as potential probiotics that alter adhesion factor gene expression. Genet Mol Res 14 (4): 12262-12275. DOI: 10.4238/2015.October.9.15. 